\title{
Effects of Culture on Green Purchase Intention, the Mediating Role of New Ecological Paradigm, Environmental Collective Efficacy and Environmental Knowledge
}

\author{
Muhammad Yawer Ansari (Corresponding author) \\ Karachi University Business School (KUBS), University of Karachi \\ KU Circular Road, University of Karachi, Karachi, Pakistan \\ E-mail: muhammadyaweransari@gmail.com
}

Dr. Danish Ahmed Siddique

Karachi University Business School (KUBS), University of Karachi

KU Circular Road, University of Karachi, Karachi, Pakistan

E-mail: daanish79@ hotmail.com

Received: December 8, 2019 Accepted: December 20, 2019 Published: December 28, 2019

doi:10.5296/ijim.v5i1.16002

URL: https://doi.org/10.5296/ijim.v5i1.16002

\begin{abstract}
This study evaluated the effects of culture value dimension on green purchase intention and analyzed the mediating role of the New Ecological Paradigm, Environmental Collective Efficacy, and Environmental Knowledge. Even though previous studies have researched the effect of culture value dimension on green purchase intention but mediating role of NEP, ECF and EN were not focused. Therefore, we proposed a new theoretical frame of green purchase intention, modifying (Ghazali et al., 2017) model focusing on cultural aspects, and further on, including Pro-environmental behavioral factor based on (Lee, 2017). The empirical validity was established through a survey of more than 200 consumers using closed-ended Likert scale type questions. The study found that the New Ecological paradigm, Environmental Collective efficacy, and Environmental Knowledge have no significant influence on green purchase intention. However, Collectivism has a significant relationship with Environmental Collective Efficacy and the New Ecological Paradigm. No mediating role has been found in
\end{abstract}




\section{Macrothink}

International Journal of Industrial Marketing

ISSN 2162-3066 2020, Vol. 5, No. 1

this study. However, four culture value dimensions that are Collectivism, Masculinity, Uncertainty Avoidance, and long-term orientation were directly analyzed with green purchase intention and results show that long-term orientation has a significant influence on green purchase intention, but collectivism, masculinity, and uncertainty avoidance have no influence on green purchase intention. The results reveal that Environmental Collective Efficacy and the New Ecological Paradigm are not significant predictors of green purchase intention, but Environmental Knowledge is an important predictor.

Keywords: Green purchase intention, New ecological paradigm, Environmental collective efficacy, Environmental knowledge, Collectivism, Masculinity, Uncertainty avoidance, Power distance, Long-term orientation 


\section{Background of the Study}

From the last few decades, environmental problems are occurring on a global scale which has switched people's attention to overcome these issues because environmental deterioration is giving adverse effects to their life by polluting air and water (Jain \& Kaur, 2004). Culture refers to collective programming of the mind which differentiates one group to another and considered a significant dimension of consumer behavior. A growing volume of consumer-related studies has concentrated on psychological factors in previous studies. Studies related to Culture impact on green consumption behavior have mostly consisted of five cultural dimensions: power distance; individualism versus collectivism; uncertainty avoidance; masculinity and long-term orientation Hofstede (1993). Most of the studies have analyzed culture orientation at the national level. However, analyzing culture values at a personal level is fruitful for two interrelated reasons. First, culture is ingrained within every individual, forming different thoughts and practices (Cho, Thyroff, Rapert, Park, \& Lee, 2013). Second, cultural values may significantly differ among individuals within the culture (McCarty \& Shrum, 2001). Responding to environmental issues has always been considered difficult. It is not easy to go green. At this stage, businessmen are facing the issue of high cost incurred ongoing green because consumers are not reluctant to make green purchases. Eco-labeling is considered helpful to communicate the consumers that products are environment-friendly. As we know, Pakistani consumers are more price-conscious and it is a potential challenge for businessmen to induce consumers toward green purchase intention.

Recently, people have become more conscious about health issues caused by environmental deterioration in Pakistan. These people are suffering from many challenges related to their health. Pakistan's newly appointed Prime minister has launched a billion-tree plantation drive to overcome climate change challenges. The government has also launched a clean Karachi drive to achieve goals related to citizen health. Pakistani Government is committed to sustainable development. In addition, not only Polythene bags have been banned in order to avoid pollution and save precious marine lives but also people are being advised to use biodegradable bags so that bags can be decomposed within a month. Many consumers recognize the dangers of environmental deterioration resulting from irresponsible consumption in Pakistan, the organization needs to have in-depth knowledge about consumer values that impact the green purchase intention to increase the effectiveness of green marketing strategies.

The influence of cultural values on customer preferences has a significant role which designers must consider in developing new products. Differences in conditions and personal factors, as well as customer preferences on a product, can be limited by culture (Crilly, Moultrie, \& Clarkson, 2004). Appearance, functionality, and price of the products are conventional attributes that are affected by the cultural values of the region (Bloch, 1995). Now Environmental concern must be considered when a product is being developed (Luchs, Naylor, Irwin, \& Raghunathan, 2010). However, environmental concern is particularly demanding to designers because they need to know which green purchase characteristics can be made part of their product design (Howarth \& Hadfield, 2006). In Pakistan, there are many studies regarding cultural influences on the green purchase intention but without mediating 
variable. Thus, the aim of this study is not only identified culture influences on green purchase intention but also mediating role of new ecological paradigm, environmental collective efficacy and environmental knowledge.

\subsection{Problem Statement}

Environmental issues are getting more significance because of climate change, Scarcity of water, natural resources and other ecological challenges. It is evident that humans influence the environment. At the same time, toxic gases are contaminating the surroundings because of which dramatic changes may occur at climate change. The extensive released carbon dioxide gas in the atmosphere is more than what can be consumed by the ecological system, ocean, and geological systems. There have been already many signs that the global population is too much for the planed and which is the cause of glaciers melting, sea levels rising, and simultaneously water scarcity and flooding are increasing. In order to protect the environment and become more sustainable during the production and consumption of products, governments in most developed countries have enforced policies to minimize environmental harm done by consumption (e.g. Pantamera in Sweden). Such a reduction in pollution has achieved by strictly prohibiting the usage of polluting ingredients (Thøgersen \& Ölander, 2006). Consumer interest in environmental protection is growing rapidly which has compelled many businessmen to make green products and consumers are considering green purchases to protect the environment. This growing interest has been in increasing demand for green labeling which helps customers to distinguish between more and less sustainable options (Horne, 2009).

All the different selections that consumers make for the products have a significant effect on the environment. Most of the time, consumers will have to make trade-offs when it comes to choices between eco-labeled products and products that have other benefits about which customer is keenly interested. In this case, a question rises what a consumer prefers: an environment-friendly product that may have low performance or other products that have excellent performance with more pollution (Windrum, Paul, Ciarli, Tommaso, \& Birchenhall, 2009). It has been found that consumers do not want to compromise on price, as we know Pakistani consumers are more price-conscious and this is a developing country in which green product usage is growing but not at a fast pace. There lies a gap between what consumers say and what they really do at the time of making purchases. This research is being carried out to know the impact of culture on green purchase intention and the mediating role of the new ecological paradigm, environmental collective efficacy, and environmental knowledge. This research is necessary because without knowing culture influences on green purchase intention, green marketers cannot easily promote their products and induce the consumer to make purchases.

\subsection{Gap Analysis}

Even though there have been many studies justifying the antecedent variable of green purchase behavior and still there remains controversy regarding the impact of the antecedent variables on green purchase behavior (Bamberg \& Möser, 2007; Mobley, Vagias, \& DeWard, 2010). Hines et al. found a weak relationship between the New Ecological paradigm and 
green purchase behavior (Hines, Hungerford, \& Tomera, 1987), while Scott and Willits showed that NEP and green purchase behavior were not related (Scott \& Willits, 1994). In addition, environmental collective efficacy, environmental knowledge, and collectivism also have an unknown relationship with green purchase intention in the last studies (Laroche, Bergeron, \& Barbaro-Forleo, 2001; Tanner \& Wölfing Kast, 2003).

Cultural dimensions have been discussed in previous studies to identify customer choices for traditional products such as product presences (Blijlevens, Creusen, \& Schoormans, 2009), functionality (Lee, Song, \& Park, 2012) and price (Suri \& Monroe, 2003). The outcome reveals that considering cultural influences on customer preferences give valuable information on customer purchasing behavior. However, these studies lack consideration, how cultural values can be used to measure customer preferences for green purchase intention. Since the results of previous studies cannot be considered into customer preferences for green purchase intention that's why it's important to analyze how cultural values can be used to measure customer preferences for green purchase intention.

Previous studies have found the influence of cultural value dimension on green products and New Ecological Paradigm influence, Environmental Collective Efficacy and Environmental Knowledge influence on green purchase intention but NEP, ECF, and EK mediating role are rarely found. Taking into consideration the above discussion cultural value dimensions that completely are not found in Pakistan research paper and mediating role of NEP, ECF and EK have been analyzed to cover the above gap.

\subsection{Research Objectives}

The aim of this study is to identify the effects of culture variables on green purchase intention and the mediating role of the New Ecological Paradigm, Environmental Collective Efficacy, and Environmental Knowledge. Cultural variables include Collectivism, Masculinity, Power distance, Uncertainty Avoidance, long term orientation and these variable's effects on green purchase intention are identified in this study. Due to environmental hazards, consumers are more reluctant to buy green products and consumer preferences vary as per their culture values. This study gathered consumers' data mostly residents of Karachi. This study's aim is also to analyze the New Ecological paradigm, Environmental Collective Efficacy and Environmental Knowledge impact on green purchase intention. The influence of cultural values on customer preference can be considered an important factor, which product developers must consider during the development of new products that are environmentally friendly.

The level of consumer awareness regarding green product usage for environment protection is still very low which needs to be raised among consumers so that these consumers prefer green products. Manufacturers are now required to ensure that their products have a lower environmental impact in order to achieve sustainable development. The manufacturer needs to know the influence of cultural values on green purchase intention which will help them in making strategies. 


\section{Macrothink}

\subsection{Research Questions}

- I believe that we as members of one community can make our environment cleaner through pro-environmental behavior.

- I know that plastic bags take many years to decompose and cause pollution.

- Humans are seriously spoiling the environment.

- Groups make better decisions than individuals.

- I will definitely consider buying a green product.

- It is important to have instructions spelled out in detail so that I always know what I'm purchasing

- It is more important for men to have a professional career than it is for women.

- People in higher positions should make most decisions without consulting people in lower positions.

- I buy products, I try to consider how my use of them will affect the environment in the future.

\subsection{Significance}

Lack of foreign market information has been considered as a major barrier by international green marketers for the successful international expansion of green products [76]. Lim et al. also focus that in order to promote green products green marketing strategies must be improved. By understanding the distinctiveness of each market will help to introduce the product and promote the product in a more effective way and can persuade the target market consumers. Greenmarket experts can expand the green market size by concentrating on the improvement of the new ecological paradigm, environmental collective efficacy, environmental knowledge, collectivism, the long-term orientation of customers. For instance, green market experts can utilize content marketing strategies to increase the new ecological paradigm and environmental knowledge of Pakistani consumers. Green marketing experts can encourage consumers' eco-friendly awareness and extend consumers' ecological awareness related to their ecological products and services. Furthermore, promoting the message that consumers' green purchases will contribute to a healthy environment of the society, city and country will be a very successful marketing strategy. The promotion of environmental collective efficacy will be an outstanding marketing strategy for Pakistani Consumers. Specially, consumers with a high propensity of Collectivism in Pakistan, it is very beneficial to promote eco-friendly products by emphasizing that eco-friendly product purchases are very effective for maintaining the environment from a collectivist viewpoint.

\section{Literature Review}

\subsection{Cultural Values and Preferences towards Green Purchase Intention}

Mind collective programming is called culture which differentiates the members of one 
human group from another (Hofstede, 1993). Culture varies from one community to another relying upon social condition (Şener \& Hazer, 2008). Depending on the personal and situational aspects of human life, customer choices of a product may be affected by cultural values (Bloch, 1995; Crilly et al., 2004; Salmi, 2008). Hofstede (1993), who was considered one of the pioneers of cross-cultural studies, classified cultural values into five dimensions: 1 . Collectivism versus individualism, (2) masculinity versus femininity, (3) high uncertainty avoidance versus low uncertainty avoidance, (4) high power distance versus low power distance and (5) long versus short term orientation.

\subsection{Collectivism}

Collectivism has been explored to influence many kinds of social behaviors. McCarty and Shrum found a positive relationship between collectivism and pro-environmental behavior (McCarty \& Shrum, 2001). This study analyzed the effects of value orientations measured at the individual level (Individualism, collectivism, and locus of control) and of economic status on environmental beliefs and behavior. The survey was carried out in Midwestern state and analysis was based on 534 respondents. Economics status had a negative relation with beliefs about the inconvenience of recycling, which ultimately turn to negatively influenced recycling behavior (McCarty \& Shrum, 2001). Precisely, collectivistic persons likely to be excited about recycling because it might be possible that they will be more cooperative and have concerned for people's health and promote group over personal values. Kim and choi determined that collectivist values have a connection to pro-environment purchase behavior. This study found that collectivistic people are more tend to make environment-friendly decisions because of they are likely to perceive significance regarding the prosperity of their group (Kim \& Choi, 2005). This study analyzed culture variables; collectivism, personality factor, materialism, along with environmental concern and attitude to have deep awareness about green consumer behavior. 224 responses were gathered from a customer using convenience sampling and the results of this study reveal a positive relationship between collectivism and green purchase intention. In addition to this, a positive relationship was found between environment concern, environment attitude and green purchase intention. Keeping the above literature into consideration, the following hypotheses have been proposed.

H1: There is a positive impact of collectivism on a new ecological paradigm.

$\mathrm{H} 2$ : There is a positive impact of collectivism on Environmental collective efficacy.

H3: There is a positive impact of collectivism on Environmental Knowledge.

H19: There is the influence of collectivism on customer green purchase intention.

\subsection{Masculinity}

Studies by (Liobikienè, Mandravickaitè, \& Bernatonienè, 2016) determined that masculinity did not have a significant influence on green purchase behavior. This study was conducted in the EU and as per this study, all culture dimensions did not have a significant influence on green purchase intention. Taking into consideration Hofstede's cultural dimensions, this study 
tried to reveal how culture variables contribute to purchase behavior. Euro barometer survey conducted in 2012 was referred and the survey was conducted upon European Union countries and findings reveal that culture dimensions have no significant impact on green purchase behavior. (Moon, Chadee, \& Tikoo, 2008) Determined that masculinity has no significant impact on green purchase intention. This study investigated consumer purchase intention toward customized products in an online selling situation. The survey was conducted in New Zealand University using 47 undergraduate students pretest which was operated to know both product stimuli for research and experience goods and important product attributes to be customized.

According to Hofstede, masculine culture or masculine society is one that emphasizes different assumptions for men and women. In a masculine society, man is anticipated to be bold, aggressive and directed on the achievement of wealth and pleasure. Women are anticipated to be rich with spiritual or intellectual values. On the contrary, Hofstede says a feminine culture on feminine society refers to the one which is conscious of for caring others and improving the quality of life (Hofstede, 2011).

Green products such as those made from recyclable materials are constructed with entrenched environmental attributes, which can affect the customers' choices on the durability and physical appearance of the product. Customers with high masculinity are more conscious regarding product functionality and quality, in contrast, customers with high femininity attributes may concentrate on the appearance of the product.

H4: There is a positive impact of masculinity on a new ecological paradigm.

H5: There is a positive impact of masculinity on environmental collective efficacy.

H6: There is a positive impact of masculinity on Environmental Knowledge.

H20: There is the influence of Masculinity on customer green purchase intention.

\subsection{Uncertainty Avoidance}

Uncertainty avoidance dimension refers to the degree to which individual members of society perceive themselves frightened by ambiguity and uncertainties and that's why they try to avoid these situations (Hofstede, 1993). Communities with high uncertainty avoidance are more likely to concentrate on life security and they are liable to stress and anxiety because of this reason they try to avoid uncertainty. On the contrary, communities with low uncertainty avoidance have a more tolerant attitude. They are competitive, keen to welcome challenges and keen to take risks in life (Hofstede, 1980). A few last studies (e.g. Frías, Rodríguez, Alberto Castañeda, Sabiote, \& Buhalis, 2012) expressed that uncertainty avoidance has a significant effect on customer choices, which may also affect customer choices for green products. For instance, green products produced from recyclable materials may enhance customers' doubts regarding the quality of products. The customers may feel that green products are of adherent quality compared with those made from virgin materials. This study aims to highlight the growing significance of culture in the field of tourism. Primary research followed a multicultural sample of 371 tourists from different European Countries. (Moon, 
Chadee, \& Tikoo, 2008) Determined that uncertainty avoidance has no significant influence on green purchase intention and (Liobikienè, Mandravickaite, \& Bernatonienè, 2016) also found no significant influence on green purchase intention.

H7: There is a positive impact of uncertainty avoidance on a new ecological paradigm.

H8: There is a positive impact of uncertainty avoidance on Environmental Collective Efficacy.

H9: There is a positive impact of uncertainty avoidance on Environmental Knowledge.

$\mathrm{H} 21$ : There is the influence of Uncertainty avoidance on customer green purchase intention.

\subsection{Power Distance}

Power distance reverses the results of power inequality and authority assigned in a society (Hofstede, 1993). In a high-power distance community, members experience hidden conflicts between powerful and powerless. There is an extensive dependency on centralization and superiors are out of reach. However, In a low power distance community, members experience harmony and trust between the powerful and powerless; everyone does not get frightened and superiors are approachable (Hofstede, 1980). The effect of power distance attributes on aspect has been examined in many studies. Issues of authenticity and responsiveness are considered less significant for high power distance customers (Furrer, Liu, \& Sudharshan, 2000). In cultures with high power distance, weak customers are possibly to bear failure from more powerful service providers. This study found a significant negative relationship between power distance and empathy, responsiveness, and reliability respectively. (Donthu \& Yoo, 1998) It also found significant negative relationship between power distance and reliability and between power distance and responsiveness. (Liobikienè, Mandravickaitè, \& Bernatoniené, 2016) Determined no significant influence of power distance on green purchase intention. It is considered that consumers residing in a society with low power distance are inconsistency with each other and they will certainly have the same affiliation towards green products made for environmental protection. Whereas, customers residing in a society with high power distance may have a low willingness for green products because of a larger gap in social status. This can be identified by considering the gap between the educated and less educated customers, for instance, it can be anticipated that educated customers will give high preference for purchasing green products as compared to the uneducated customers because they are aware of the benefits of green products and its effect on the environment.

H10: There is a positive impact of power distance on the new ecological paradigm.

H11: There is a positive impact of power distance on Environmental Collective Efficacy.

H12: There is a positive impact of power distance on Environmental Knowledge.

H22: There is the influence of Long-term orientation on customer green purchase intention 


\subsection{Long Term Orientation}

Long term orientation refers to promoting virtue orientation towards future rewards, especially in determination and austerity (Hofstede, 1993). Previous studies (Yoo \& Donthu, 2005) have found that long term orientation has a significant effect on the purchasing intention of customers. This study determined the relationship between cultural orientation and consumer ethnocentrism and each Hofstede's five cultural dimensions effects on consumer ethnocentrism. The findings reveal that ethnocentrism has a positive relationship with collectivism, masculinity, and uncertainty avoidance but has a negative relationship with consumer purchase intention concerning foreign products and perceived quality of foreign products (Yoo \& Donthu, 2005). This study's purpose was to analyze consumers' influence focusing on collectivism and long-term orientation culture values on their purchase intention with the connection of environment-friendly products. The survey was conducted taking 682 shoppers' responses infamous Vietnamese electrical appliance stores. The findings explore that consumers with high adherence to collectivism and long-term orientation likely to engage in green purchase intention because of their positive environmental attitude (Nguyen, Lobo, \& Greenland, 2017). Looking at the impact of long-term orientation on ECCB is also one of the important contributions of this paper since environmental consciousness requires a long-term view of the world around us. Building upon the adaptation and extension of past research in the area, data are collected from 97 respondents, 80 percent of whom are undergraduate college students, and analyzed through commonly used statistical methods. The measures used are similar to those used in previous studies. (Gul, 2013).

Performance and quality are considered one of the most important aspects. Green products are produced to minimize the usage of natural resources and minimize energy consumption so that environmental impact can be minimized. Customers having a long-term orientation mindset are conscious about the potential usage of the product such as energy consumption and quality. Some customers are keenly interested in long term orientation. That's why long-term orientation seems to have a significant influence on customer preferences for green products.

H13: There is a positive impact of long-term orientation on the new ecological paradigm.

H14: There is a positive impact of long-term orientation on Environmental Collective Efficacy.

H15: There is a positive impact of long-term orientation on Environmental Knowledge.

\subsection{New Ecological Paradigm (NEP)}

Although various studies have been done to explore the relationship between NEP and pro-environmental behaviors, and no obvious relationship has been found. Donalp and Van Liere explored that NEP has insignificant impacts on pro-environmental behavior (Dunlap \& Liere, The "New Environmental Paradigm", 2008) while (HINES \& HAROLD R, 1987) found a weak relationship between NEP and green purchase behavior. Much empirically-based environmental behavior research conducted in the last year's obtained enough studies representatives of the wide academic base. The features and findings of these 
studies served as the data for the meta-analysis (HINES \& HAROLD R, 1987).

(Dunlap, Liere, Mertig, \& Jones, 2000) This study revised New Ecological Paradigm scale developed to improve the original one in many aspects: (1) It considers a wider range of facets of an environment-friendly worldview, (2) It proposed an equivalence set of pro- and anti- NEP items, (3) it avoids outmoded terminology. Findings reveal that items can be perceived as an internally regular summarized rating scale and signify moderated growth in pro- NEP Responses among Washington residents over the 14 years since the original study was conducted. It has been found that a revised NEP scale has slightly more internal consistency than the original one. Concerning environmental attitude studies, there are two types of environmental attitude which are used to anticipate ecological behavior: attitudes toward ecological behavior and attitudes toward the environment in general (Hines et al., 1987). Attitude toward ecological behavior is eco-friendly actions such as recycling or becoming part of eco- friendly activities. While the objects of attitude toward the environment are some aspects such as air/water quality. Environmental attitude towards ecological behavior is the Ajzen and Fishbein's theory of reasoned action model (Azjen, 1980).

The New Environmental Paradigm refers to a member single component method of environmental attitude (Dunlap \& Van Liere, 1978). NEP is a general approach for checking attitudes toward the environment, initially conferred by (Dunlap \& Van Liere, 1978) and afterward advanced to New Ecological Paradigm (NEP) (Dunlap, Van Liere, Mertig, \& Jones, 2000). NEP scale has developed into one of the most extensive measures of environmental attitude all over the world and has been used in various studies (Hawcroft \& Milfont, 2010).

H16: There is the influence of the new ecological paradigm on customer green purchase intention.

\subsection{Environmental Collective Efficacy}

Homburg and Stolberg have found in their studies that people's contribution in pro-environmental activities cannot be anticipated by self-efficacy but rather it can be anticipated by collective efficacy (Andreas Hombur, 2006).

Similarly, Bonniface and Henley constructed that those people participating in a household waste management program are more expected to have beliefs that the waste problem could be minimized by the participation of all members that those who do not participate (Bonniface \& Henley, 2016). Bandura determined collective efficacy beliefs by asking members of a group to analyze the group's capability to jointly get required results (Bandura, 2000). Thus, this study concludes that environmental collective efficacy refers to one's belief about his/her group's capability to resolve environmental problems effectively.

The norm-activation model (NAM) and the theory of planned behavior (TPB) are mostly used by pro-environmental behavior studies for analyzing pro-environmental behavior. The Norm activation model explains environmental behavior as more socially driven. TPB model explains arrogance depending on rational choice models as an immediate motivator. The TPB 
model views that consumers not only acknowledge their environmental attitude toward the green purchase behavior but also consider efficiency to express green purchase behavior when forming pro-environmental purchase intention. In addition, by considering that the result from environmental uses is an enhancement in social well-being on a large scale, collective efficacy judgment may have a stronger effect on green purchase intention than self-efficacy. Furthermore, if the study model were made for Asian countries in which collectivism is more effective, environmental collective efficacy would be more important.

Seijts and Latham expressed that strong collective efficacy which is the belief among people that the members within a group have the capability to get required outcomes together might be more compelling the individuals' participation as far as social problems are concerned (Seijts, 2000)

H17: There is the influence of Environmental collective efficacy on customer green purchase intention.

\subsection{Environmental Knowledge}

Polonsky et al. declared that environmental knowledge can be common or definite (Michael Jay Polonsky, 2012). Whereas few studies have recognized environment definite knowledge (Deborah J.C. Brosdahl, 2010), other studies have used general environmental knowledge (Michel Laroche, 2001), (Mostafa, 2006), or both (Gerald E. Fryxell, 2003), (Nelson A. Barber, 2009) to determine relationship between environmental knowledge and pro-environmental behaviors. The last studies concerning the effect of definite environmental knowledge and common environmental knowledge on pro-environmental behaviors contributed to mixed results. Barber et al. analyzed the relationship between common environmental knowledge and definite environmental knowledge and found that product definite environmental knowledge had a significant effect on green purchase intention, on the contrary, common environmental knowledge had an insignificant effect (Nelson A. Barber, 2009). However, (Michael Jay Polonsky, 2012) determined that both common and definite environmental knowledge was certainly related to environmental behaviors (Michael Jay Polonsky, 2012). Barber et al. contended that environmental knowledge, common environmental knowledge, and definite environmental knowledge might be associated with various types of behavior (Nelson A. Barber, 2009).

Environmental Knowledge is considered one of the most significant variables to anticipate pro-environmental behavior. Fryxell and Lo determined environmental knowledge as the extent to which individuals know about environmental issues and the knowledge about the facts, ideas, and relationships about the ecological community (Gerald E. Fryxell, 2003).

(Michael Jay Polonsky, 2012) declared that environmental knowledge can be common or definite. General knowledge of facts, concepts, and relationships concerning the natural environment and its major ecosystems. Environmental knowledge can be general in nature, such as awareness of environment-friendly products or more specific knowledge on issues such as recycling or carbon offset programs. The findings of the study suggest that a positive relationship was found between general and carbon-specific knowledge (Michael Jay 


\section{Macrothink}

Polonsky, 2012).

In the meantime, Brucks defined consumer product knowledge as subjective and objective. Subjective knowledge expresses an individual's approach of how much/ he knows, and objective knowledge expresses the method that an individual certainly knows (Brucks, 1985). Ellen analyzed the effects of objective and subjective knowledge reprocessing and reprocessing based purchase decisions (Ellen, 1994). He found a significant relationship.

H18: There is the influence of Environmental knowledge on customer green purchase intention.

\subsection{Theoretical Framework}

This study analyzed the effects of Hofstede's (1993) five culture dimensions on green purchase intention the mediating role of NEP, ECE, and EK. This research is based on different last studies but especially (Ghazali, et al., 2017) and lee (2017).

(Ghazali, et al., 2017) Determined the influence of culture value dimensions on customer preferences for green products. This study took a sample of 615 Malaysian citizens and the data were analyzed using the structure modeling approach. The results reveal that there are three cultural dimensions that have a significant influence on customer preferences for green products these dimensions are uncertainty avoidance, long term orientation, and power distance and insignificant influence on collectivism and masculinity.

(Lee, 2017) This study purpose to analyze the influence of the new ecological paradigm, environmental collective efficacy, environmental knowledge and collectivism on green purchase intention. The results of this study reveal that the new ecological paradigm, environmental collective efficacy, environmental knowledge, and collectivism are direct preliminary of green purchase intention in China. It was found that environmental collective efficacy and environment knowledge have a direct influence on green purchase intention in Korea.

Based on the above studies this research has been carried out but this researcher is analyzing the mediating role of three variables. NEP, ECE, and EK are causing mediation between culture dimensions and green purchase intention. 


\section{Macrothink}

2.11 Research Framework

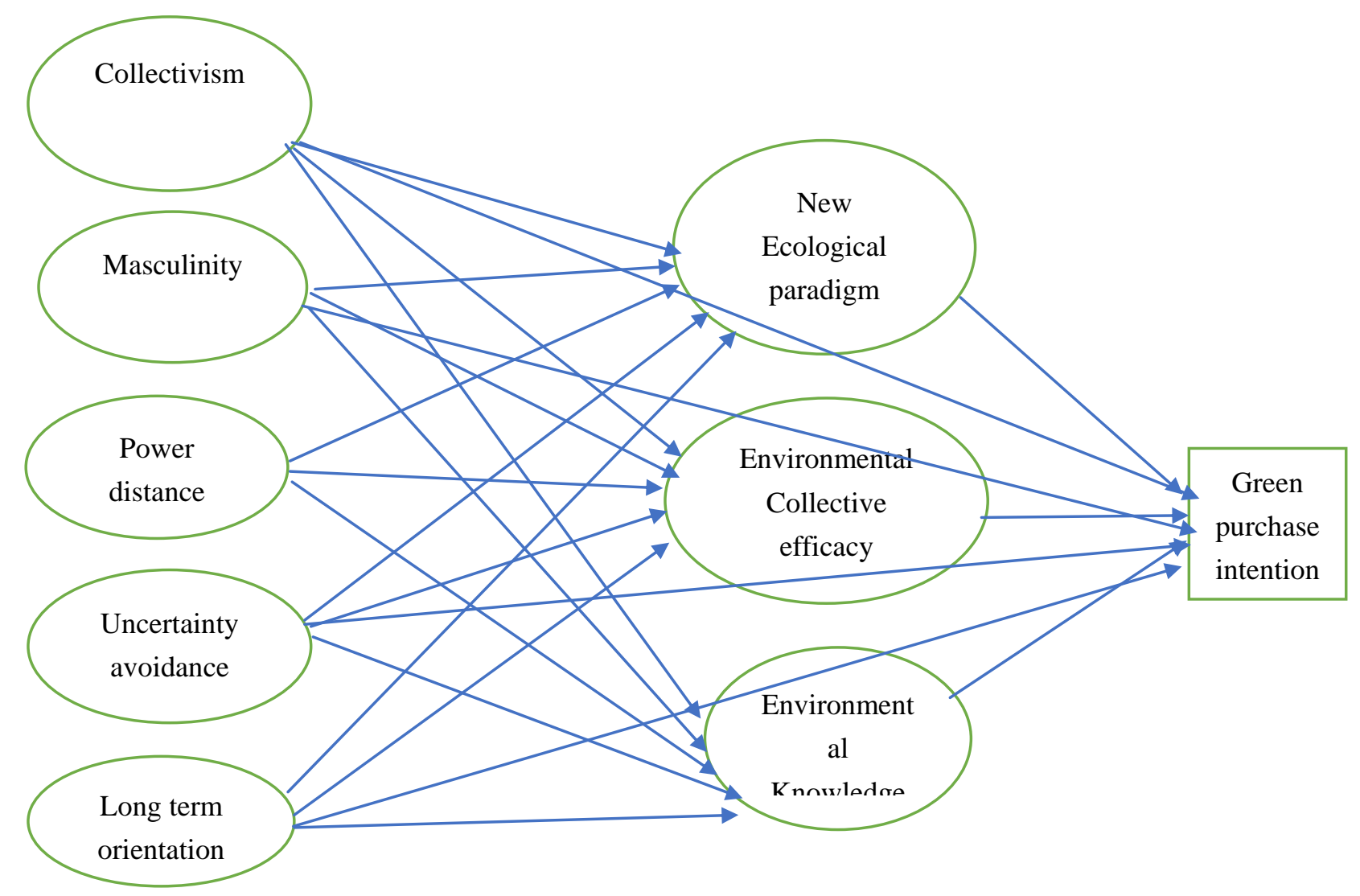

Figure 1. Research framework

According to the figure 1 research framework, there are five cultural dimensions which are collectivism, masculinity, power distance, uncertainty avoidance and long term orientation on green purchase intention. Three mediating variables (i.e. new ecological paradigm, environmental collective efficacy, and environmental knowledge).

\section{Research Methodology}

\subsection{Questionnaire Design}

An online survey was used to collect data. A total of approximately 216 responses to the questionnaire were collected from the online survey. The questionnaire was classified into five Sections. The first section was about respondents' Name, age, gender, location, qualification, and income per month. The second section consisted of the new ecological paradigm (three items), environmental collective efficacy (three items) and environmental knowledge (three items). The third section consisted of collectivism (four items) and green purchase intentions (three items). The fourth section consisted of uncertainty avoidance (three items) and masculinity (three items). The last section consisted of power distance (three items) and long-term orientation (three items). 


\section{Macrothink}

Table 1. Demographic characteristics

\begin{tabular}{|l|l|r|}
\hline Items & & Frequency (\%) \\
\hline Gender & Male & $68 \%$ \\
& Female & $32 \%$ \\
\hline \multirow{5}{*}{ Age } & $21-25$ & $47.10 \%$ \\
& $26-30$ & $30.30 \%$ \\
& $31-35$ & $11.80 \%$ \\
& $36-40$ & $5 \%$ \\
& More than 40 & $5.90 \%$ \\
\hline \multirow{5}{*}{ Education } & Bachelors & $47.10 \%$ \\
& Masters & $39.50 \%$ \\
& M. Phil & $10.90 \%$ \\
& PHD & $0.80 \%$ \\
& Other & $0.16 \%$ \\
\hline \multirow{5}{*}{ Monthly Income } & Less than 25,000 & $42.90 \%$ \\
& $26,000-30,000$ & $14.30 \%$ \\
& $31,000-35,000$ & $9.20 \%$ \\
& $36,000-40,000$ & $6.70 \%$ \\
& More than 40,000 & $26.90 \%$ \\
\hline
\end{tabular}

Table 1 expresses the demographic characteristics of respondents. Descriptive results show that $68 \%$ Male contributed to data collection whereas females contributed $32 \% .47 .10 \%$ of respondents were between 21 and 25 years old. $30.30 \%$ of respondents were between 26 and 30 years old. $11.80 \%$ of the respondents were between 31 and 35 years old. Approximately, $10 \%$ of respondents were between 36 and 40 years old. As far as respondents' Education is concerned, $47.10 \%$ were bachelors, $39.50 \%$ had master's degrees, $10.90 \%$ were M. Phil students, $0.80 \%$ were Ph.D., $0.80 \%$ were intermediate students and $0.80 \%$ student's graduation was continued. Regarding respondent's monthly income, $42.90 \%$ were earning less than 25,000 and approximately 30\% were earning between 26,000 and 40,000.

\subsection{Descriptive Statistic}

Table 2. Descriptive statistic

\begin{tabular}{|l|l|r|r|r|}
\hline Constructs & \multicolumn{1}{|c|}{ Measurements Items } & Mean & \multicolumn{1}{|c|}{$\begin{array}{l}\text { Standard } \\
\text { Deviation }\end{array}$} & $\begin{array}{l}\text { Standard } \\
\text { error }\end{array}$ \\
\hline & $\begin{array}{l}\text { I believe that we as members of one community } \\
\text { can make our environment cleaner through } \\
\text { pro-environmental behavior. }\end{array}$ & 4.02 & 1.283 & 0.088 \\
\hline $\begin{array}{l}\text { Environmental } \\
\text { Collective } \\
\text { Efficacy }\end{array}$ & $\begin{array}{l}\text { I believe that we as members of one community } \\
\text { can make our environment cleaner through } \\
\text { pro-environmental behavior. }\end{array}$ & 3.967 & 1.272 & 0.087 \\
\hline
\end{tabular}




\begin{tabular}{|c|c|c|c|c|}
\hline & $\begin{array}{l}\text { I believe that we as members of one community } \\
\text { can come up with creative ideas to help solve } \\
\text { environmental problems effectively. }\end{array}$ & 4.033 & 1.261 & 0.086 \\
\hline & $\begin{array}{l}\text { I know how to preserve and not cause damage to } \\
\text { the environment }\end{array}$ & 1.117 & 0.322 & 0.022 \\
\hline \multirow[t]{3}{*}{$\begin{array}{l}\text { Environmental } \\
\text { Knowledge }\end{array}$} & $\begin{array}{l}\text { I know that plastic bags take many years to } \\
\text { decompose and cause pollution. }\end{array}$ & 1.019 & 0.136 & 0.009 \\
\hline & I know the causes and effects of "global warming. & 1.065 & 0.248 & 0.017 \\
\hline & Humans are seriously spoiling the environment. & 4.079 & 1.178 & 0.081 \\
\hline \multirow[t]{4}{*}{$\begin{array}{l}\text { New } \\
\text { Ecological } \\
\text { Paradigm } \\
\end{array}$} & $\begin{array}{l}\text { When humans interfere with nature it often } \\
\text { produces terrible consequences. }\end{array}$ & 3.902 & 1.165 & 0.080 \\
\hline & $\begin{array}{l}\text { If things continue their present course, we will } \\
\text { soon experience a major ecological disaster. }\end{array}$ & 4.065 & 1.099 & 0.075 \\
\hline & Groups make better decisions than individuals. & 3.995 & 1.103 & 0.075 \\
\hline & It is better to work in a group than alone. & 3.977 & 1.140 & 0.078 \\
\hline \multirow[t]{3}{*}{ Collectivism } & $\begin{array}{l}\text { Decisions made by individuals are usually of } \\
\text { higher quality than decisions made by groups. }\end{array}$ & 3.360 & 1.338 & 0.091 \\
\hline & $\begin{array}{l}\text { I would not support my workgroup if I felt they } \\
\text { were wrong. }\end{array}$ & 3.790 & 1.154 & 0.079 \\
\hline & I will definitely consider buying a green product. & 1.393 & 0.778 & 0.053 \\
\hline \multirow[t]{3}{*}{$\begin{array}{l}\text { Green purchase } \\
\text { intention }\end{array}$} & I will prioritize a green product when shopping. & 1.463 & 0.808 & 0.055 \\
\hline & $\begin{array}{l}\text { I will recommend a green product to the people } \\
\text { around me. }\end{array}$ & 1.430 & 0.806 & 0.055 \\
\hline & $\begin{array}{l}\text { It is important to have instructions spelled out in } \\
\text { detail so that I always know what I'm purchasing }\end{array}$ & 3.897 & 0.959 & 0.066 \\
\hline \multirow[t]{3}{*}{$\begin{array}{l}\text { Uncertainty } \\
\text { Avoidance }\end{array}$} & $\begin{array}{l}\text { It is important to closely follow instructions and } \\
\text { procedures while consuming green products. }\end{array}$ & 3.953 & 1.015 & 0.069 \\
\hline & $\begin{array}{l}\text { Instructions for operations are important in the } \\
\text { consumption of green products. }\end{array}$ & 3.944 & 1.095 & 0.075 \\
\hline & $\begin{array}{l}\text { It is more important for men to have a professional } \\
\text { career than it is for women. }\end{array}$ & 3.715 & 1.255 & 0.086 \\
\hline \multirow[t]{3}{*}{ Masculinity } & $\begin{array}{l}\text { Men usually solve problems with logical analysis; } \\
\text { women usually solve problems with intuition. }\end{array}$ & 3.561 & 1.192 & 0.081 \\
\hline & $\begin{array}{l}\text { Solving difficult problems usually requires an } \\
\text { active forcible approach, which is typical of men. }\end{array}$ & 3.551 & 1.243 & 0.085 \\
\hline & $\begin{array}{l}\text { People in higher positions should make most } \\
\text { decisions without consulting people in lower } \\
\text { positions }\end{array}$ & 3.206 & 1.396 & 0.095 \\
\hline $\begin{array}{l}\text { Power } \\
\text { distance }\end{array}$ & $\begin{array}{l}\text { People in higher positions should not ask the } \\
\text { opinions of people in lower positions too } \\
\text { frequently. }\end{array}$ & 3.065 & 1.462 & 0.100 \\
\hline
\end{tabular}




\begin{tabular}{|l|l|r|r|r|}
\hline & $\begin{array}{l}\text { People in higher positions should not ask the } \\
\text { opinions of people in lower positions too } \\
\text { frequently. }\end{array}$ & 2.977 & 1.552 & 0.106 \\
\hline & $\begin{array}{l}\text { When I buy products, I try to consider how my use } \\
\text { of them will affect the environment in the future. }\end{array}$ & 3.626 & 1.109 & 0.076 \\
\hline $\begin{array}{l}\text { Long term } \\
\text { orientation }\end{array}$ & $\begin{array}{l}\text { When I have a choice between two equal products, } \\
\text { I always purchase the one which is less harmful to } \\
\text { other people and the environment. }\end{array}$ & 3.907 & 1.071 & 0.073 \\
\hline & I try only to buy products that can be recycled. & 3.598 & 1.259 & 0.086 \\
\hline
\end{tabular}

Items related to Environmental Collective Efficacy have the mean score in range 1.11 to 4.02 while the same items deviate in range 0.126 to 1.28 . The overall mean values suggest responses are more closely toward the "60\% strong Agreement" at a five-point Likert scale. Items related to Environmental knowledge have a mean score of 1.065 to 1.117 and the same items deviate in range 0.248 to 0.322 . This also suggests that responses are most closely to "90\% yes" at a nominal scale. Items related to New Ecological Paradigm have a mean score in range 3.902 to 4.079 and the same items deviate in the range from 1.099 to 1.178 which reveals that responses are most closely to " $60 \%$ strong agreement" at five-point Likert scale. Items related to Collectivism have a mean score in range 3.360 to 3.97 and the same items deviate in range 1.103 to 1.154 . The overall mean values suggest responses are more closely toward the " $50 \%$ agreement" at a five-point Likert scale. Items related to Green purchase intention have a mean score in range 1.393 to 1.463 and the same items deviate in range 0.778 to 0.808 . The overall mean values suggest responses are more closely toward " $75 \%$ Yes" at a nominal scale. Items related to Uncertainty Avoidance have a mean score in range 3.897 to 3.953 and the same items deviate in the range from 0.959 to 1.095 . The overall mean values suggest responses are most closely toward the " $60 \%$ strong Agreement" at a five-point Likert scale. Items related to Masculinity have a mean score range of 3.55 to 3.715 and the same items deviate in range 1.192 to 1.255 . The overall mean values suggest responses are more closely toward " $30 \%$ strong agreement" at a five-point Likert scale.

Items related to Power distance have a mean score in range 2.977 to 3.206 and the same items deviate in range 1.396 to 1.552 . The overall mean values suggest responses are most closely toward the " $30 \%$ agreement" at a five-point Likert scale.

Items related to Long term Orientation have a mean score in range 3.598 to 3.626 and which deviate in range 1.071 to 1.29 . The overall mean values suggest responses are most closely toward the " $40 \%$ agreement" at a five-point Likert scale.

\section{Structural Equation Modeling}

To test the study hypothesis, we have used the structural equation model (SEM) whereas the testing has been gone through Smart PLS software. Moreover, to evaluate the indirect and direct effects of all the constructs the testing was done. The use of (SEM) structural equation model has been observed to be a foremost procedure that has been used below different 
regression models and methods (Barron \& Kenny, 1986). It used to evaluate the structural relationship between exogenous and endogenous variables. It includes factor analysis and multivariate analysis. Moreover, the equation of regression targets at explaining each construct to assess the cause and effect relationship while all of the factors in the causal model could demonstrate their cause and effect at the exact time. Likewise, the idea of using this model ensures to apply the technique of bootstrapping which has been viewed as reasonable for both small and large sample sizes and does not require any kind of indirect effect (Hayes, 2013). In order to check all direct and indirect effects, a technique has been implemented which is known as bootstrapping (Shrout \& Bolger, 1986).

\subsection{Measurement of Outer Model}

The goal of the measure of fit in the measurement model is to study the reliability and validity of the instrument and to check its reliability and validity we perform a test of convergent validity and discriminant validity in software naming Smart PLS.

\subsection{Composite Reliability}

Reliability implies the stability of questionnaire outcomes. For a similar target population, at whatever point the questioner reutilizes the questionnaire it will give a similar outcome. It demonstrates inside consistency \& repeatability of the survey are high. The primary measure for unwavering quality is to maintain a strategic distance from unfairness in research. In this manner, it tends to be improved by testing the pursuit procedure and investigation, as is done utilizing diverse research and examination techniques or different researchers. This also incorporates the dependability and legitimacy of the exploration.

The reliability of the measurement instruments was evaluated using composite reliability. All the values were above the normally used threshold value i.e. 0.70. This is the accepted reliability value range. Estimation of reliability can be done by the degree of constancy that lies amongst various variables (Hair , 2010). Below is the table of composite reliability.

Table 3. Composite reliability

\begin{tabular}{|l|r|}
\hline Variables & Composite Reliability \\
\hline Collectivism & 0.886 \\
\hline ECE & 0.947 \\
\hline EK & 1 \\
\hline GPI & 1 \\
\hline Masculinity & 0.898 \\
\hline NEP & 0.913 \\
\hline Power distance & 0.932 \\
\hline Uncertainty Avoidance & 0.91 \\
\hline long term orientation & 0.893 \\
\hline
\end{tabular}




\section{Macrothink}

\subsection{Factor Loadings Significant}

Below is the mentioned table of (CFA) confirmatory factor analysis with the loadings. Construct with the loading of .5 are consider as strong loading variables whereas the constructs with the loading of below .5 are considered as less is better to be removed from the table.

Table 4. Factor loadings significant

\begin{tabular}{|l|l|c|c|c|}
\hline Variables & Item & Factor Loading & CR & AVE \\
\hline Collectivism & GBI & 0.903 & 0.886 & 0.796 \\
\hline ECE & WGA & 0.881 & & \\
\hline & CUC & 0.952 & 0.947 & 0.855 \\
\hline & ECW & 0.895 & & \\
\hline EK & MCE & 0.926 & 1 & 1 \\
\hline GPI & PDE & 1 & 1 & 1 \\
\hline Masculinity & GPS & 1 & 0.898 & 0.747 \\
\hline & MPC & 0.83 & & \\
\hline & PLA & 0.788 & & \\
\hline NEP & SDP & 0.965 & 0.913 & 0.778 \\
\hline & EMD & 0.824 & & \\
\hline & HIN & 0.907 & & \\
\hline Power distance & HSE & 0.912 & 0.932 & 0.821 \\
\hline & ACI & 0.933 & & \\
\hline & ATO & 0.866 & & \\
\hline Uncertainty Avoidance & FIP & 0.911 & & \\
\hline & ICG & 0.855 & & \\
\hline & ISO & 0.882 & & \\
\hline long term orientation & BPR & 0.868 & & \\
\hline & BPU & 0.853 & 0.893 & 0.735 \\
\hline & TEP & 0.854 & & \\
\hline
\end{tabular}

CR refers to Composite Reliability. It should be within the range of $0.60-0.70$ for exploratory studies.

AVE refers to the average variance extracted. It should be more than 0.5 .

The convergent validity consist of measuring the factor loadings, composite reliability (CR > 0.7 ) and average variance extracted (AVE > 0.5). It is suggested that factor loading should be within a range of 0.4-0.7 or greater. However, if excluding the factor loading can enhance the $\mathrm{AVE}$ and $\mathrm{CR}$, then removing the lowest items in the assigned construct is desirable. 


\subsection{Convergent Validity}

Convergent validity is the level of agreement in at least two measures of a similar construct (Carmines \& Zeller, 1979). Convergent validity was assessed by inspection of variance mined for each factor (Fornell \& Larcker, 1981). Conferring to (Fornell \& Larcker, 1981), if the variance extracted value is greater than 0.5 then convergent validity is established, and the result is drawn that the loadings are good but less than 0.5 are termed as less effective for the study.

The following table displays the result.

\begin{tabular}{|l|r|r|r|}
\hline Variables & Cronbach's Alpha & Composite Reliability & \multicolumn{2}{|c|}{$\begin{array}{l}\text { Average } \\
\text { Extracted (AVE) }\end{array}$} \\
\hline Collectivism & 0.886 & 0.886 & 0.796 \\
\hline ECE & 0.946 & 0.947 & 0.855 \\
\hline EK & 1 & 1 & 1 \\
\hline GPI & 1 & 1 & 1 \\
\hline Masculinity & 0.896 & 0.898 & 0.747 \\
\hline NEP & 0.912 & 0.913 & 0.778 \\
\hline Power distance & 0.932 & 0.932 & 0.821 \\
\hline Uncertainty Avoidance_- & 0.91 & 0.91 & 0.771 \\
\hline long term orientation_- & 0.893 & 0.893 & 0.735 \\
\hline
\end{tabular}

\subsection{Discriminant Validity}

Discriminate validity can be defined as any single construct when differs from other constructs in the model (Carmines \& Zeller, 1979). Discriminate validity results are satisfactory when the constructs are having an AVE loading more than 0.5 which means that a minimum of $50 \%$ of the variance was taken by the construct (Chin, 1998). Discriminate validity is established if the elements which are in diagonal are significantly higher than those values in off-diagonal in the parallel rows and columns. Discriminant Validity tests are being conducted in order to see whether non-related ideas or measurements are in fact unrelated or not. An effective assessment of discriminant legitimacy demonstrates that a trial of an idea isn't exceptionally associated with different tests intended to quantify hypothetically various ideas. The table for Discriminant Validity is given below: 
Table 6. Discriminant validity

\begin{tabular}{|l|c|c|c|c|c|c|c|c|c|}
\hline & Collectivism & ECE & EK & GPI & Masculinity & NEP & PD & UA & LO \\
\hline Collectivism & 0.892 & & & & & & & & \\
ECE & 0.675 & 0.925 & & & & & & & \\
EK & -0.091 & -0.222 & 1 & & & & & & \\
GPI & -0.21 & -0.243 & 0.224 & 1 & & & & & \\
Masculinity & 0.613 & 0.408 & -0.231 & -0.19 & 0.864 & & & & \\
NEP & 0.683 & 0.804 & -0.087 & -0.204 & 0.456 & 0.88 & & & \\
Power & 0.37 & 0.256 & -0.121 & -0.248 & 0.624 & 0.24 & 0.906 & & \\
distance & 0.784 & 0.751 & -0.018 & -0.295 & 0.541 & 0.82 & 0.365 & 0.878 & \\
Uncertainty & & & & & & & & \\
Avoidance_ & 0.499 & 0.499 & -0.148 & -0.458 & 0.6 & 0.51 & 0.661 & 0.66 & 0.857 \\
long term & & & & & & & \\
orientation_ & 0.499 & & & & & & & \\
\hline
\end{tabular}

\subsection{Model Fit Measures}

The fitness of the model in SEM-PLS is defined by various measures such as standardized root-mean-square residual (SRMR), and the exact model fits like d_ULS and d_G, Normed Fit Index (NFI), and $\chi^{2}$ (Chi-square). The model fit measures consisting of the measured value of both the saturated model, as well as the estimated model, are reported in the above Table. The saturated model assesses the correlation between all constructs. The estimated model, on the other hand, takes model structure into account and is based on the total effect scheme.

Table 7. Fit summary

\begin{tabular}{|c|c|c|}
\hline Fit Summary & & \\
\hline & Saturated Model & Estimated Model \\
\hline SRMR & 0.038 & 0.051 \\
\hline d_ULS & 0.357 & 0.662 \\
\hline d_G & 0.508 & 0.569 \\
\hline Chi-Square & 535.473 & 589.846 \\
\hline NFI & 0.88 & 0.868 \\
\hline
\end{tabular}

\subsection{Hypothesis Testing}

In PLS-SEM, bootstrapping is one of the key strides, which gives the data of constancy of factor guesstimate. Sub-tests are drawn everywhere from the first example including substitution, in this process (Hair, Matthews, Matthews, \& Sarstedt, 2017). Bootstrapping provides information on the stability of the coefficient estimate. In this process, a large 


\section{Macrothink}

number of sub-samples are drawn from the original sample with replacement (Hair et al. 2016). After running the bootstrap routine, SMART PLS shows the t-values for structural model estimates derived from the bootstrapping procedure. The results of path coefficients for all the hypotheses are shown in the following table. The t-value greater than $1.96 \mathrm{p}$ $<.005)$ shows that the relationship is significant at 95\% confidence level $(\alpha=0.05)$. Paths showing whether the relationship between measured and latent variables are significant or not. The path diagram showed in figure 2 .

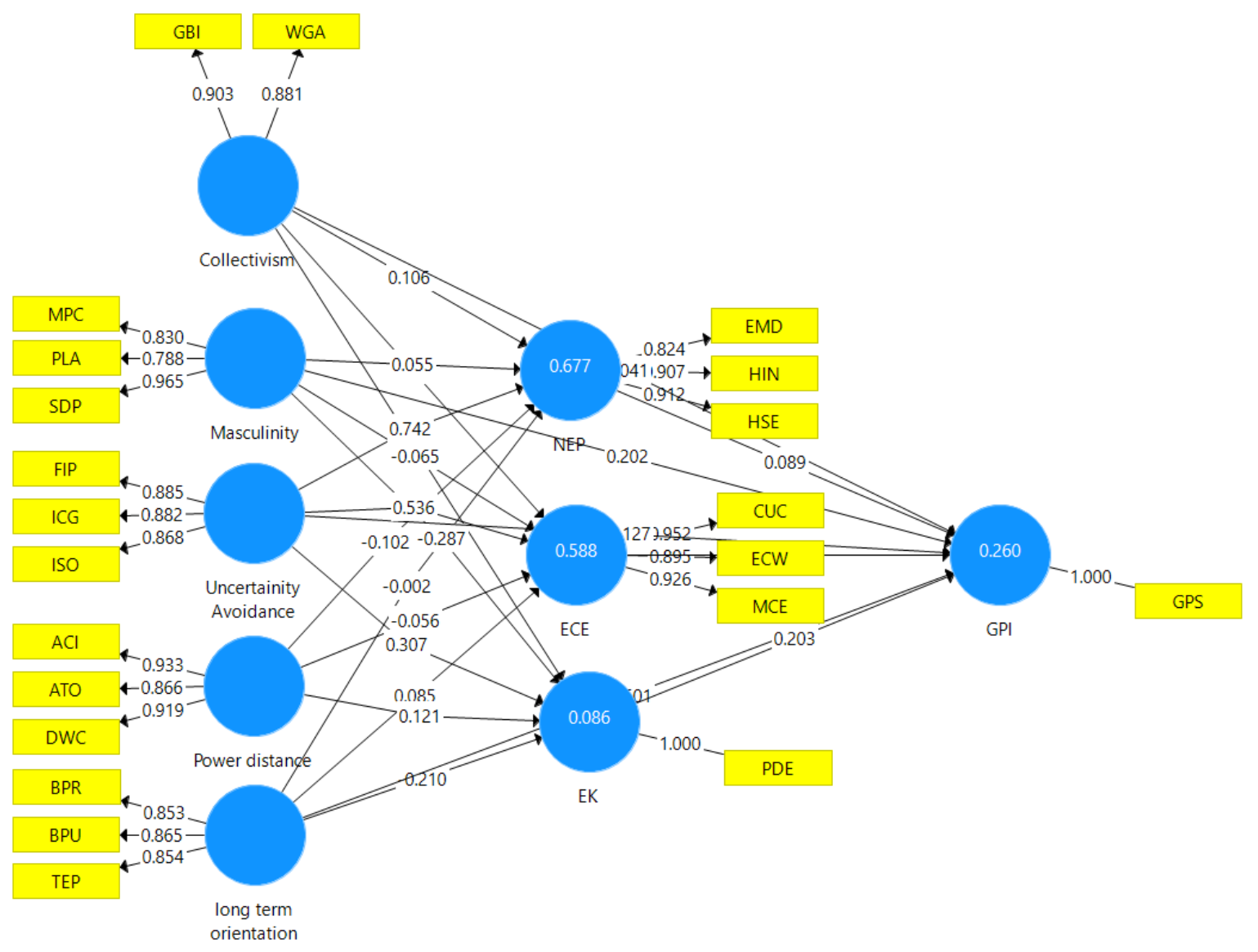

Figure 2. Results after bootstrapping

According to Hair et al. (2014), bootstrapping with 5000 sub-samples is suggested to analyze t- value scores. Bootstrapping with 3000 samples were performed in this study. T - Values are shown in figure 3. It can be observed in table 4 that there is seven relationships with high Tvalue scores (i.e. Collectivism, Environmental Knowledge, Masculinity, Uncertainty avoidance, long-term orientation and uncertainty avoidance with the new ecological paradigm. On the Contrary, collectivism's impact on environmental knowledge, collectivism influence on green purchase intention, have a low t- value score.

Masculinity impact on environmental collective efficacy and masculinity impact on new 


\section{Ml Macrothink}

ecological paradigm have low t- value scores. In contrast, Masculinity impact on environmental collective efficacy and environmental knowledge have a high $\mathrm{T}$-value score.

Power distance impact on environmental collective efficacy, environmental knowledge, and new ecological paradigm have a low T- value score.

Uncertainty avoidance impact on environmental collective efficacy and new ecological paradigm have a high $\mathrm{T}$ - value score. On the contrary, uncertainty avoidance impact on environmental knowledge and its influence on green purchase intention have a low t-value score.

Long term orientation influence on green purchase intention has a high T- value score but long-term orientation impact on environmental collective efficacy, environmental knowledge, and new ecological paradigm have low T- value score.

Environmental knowledge influence on green purchase intention has a high T -value score. In contrast, Environmental collective efficacy and new ecological paradigm have a low T- value score. However, considering the t- values achieved in this study, it can be concluded that collectivism has a significant impact on environmental collective efficacy. Environmental knowledge has a significant influence on green purchase intention. Masculinity has a significant impact on environmental knowledge. Uncertainty avoidance has a significant impact on environmental collective efficacy and New ecological paradigm. Long term orientation has a significant influence on green purchase intention.

Table 8. Results of the structure model

\begin{tabular}{|l|l|l|l|l|l|l|l|}
\hline Hypothesis & Description & $\begin{array}{l}\text { Original } \\
\text { Sample (O) }\end{array}$ & $\begin{array}{l}\text { Sample } \\
\text { Mean (M) }\end{array}$ & $\begin{array}{l}\text { Standard Deviation } \\
(\mathrm{STDEV})\end{array}$ & $\begin{array}{l}\text { T Statistics } \\
(\mid \mathrm{O} / \mathrm{STDEV})\end{array}$ & $\begin{array}{l}\text { P } \\
\text { Values }\end{array}$ & Result \\
\hline $\begin{array}{l}\text { There is a } \\
\text { Positive impact } \\
\text { of collectivism } \\
\text { on ECE }\end{array}$ & $\begin{array}{l}\text { Collectivism } \\
->\text { ECE }\end{array}$ & 0.269 & 0.262 & 0.116 & 2.325 & 0.02 & supported \\
\hline $\begin{array}{l}\text { There is a } \\
\text { Positive impact } \\
\text { of collectivism } \\
\text { on EK }\end{array}$ & $\begin{array}{l}\text { Collectivism } \\
\text {-> EK }\end{array}$ & -0.047 & -0.032 & 0.173 & 0.271 & 0.786 & not \\
\hline $\begin{array}{l}\text { There is an } \\
\text { influence of } \\
\text { collectivism on } \\
\text { GPI }\end{array}$ & $\begin{array}{l}\text { Collectivism } \\
->\text { GPI }\end{array}$ & -0.013 & -0.007 & 0.097 & supported \\
\hline $\begin{array}{l}\text { There is a } \\
\text { Positive impact } \\
\text { of collectivism } \\
\text { on NEP }\end{array}$ & $\begin{array}{l}\text { Collectivism } \\
\text {-> NEP }\end{array}$ & 0.172 & 0.167 & 0.095 & 0.133 & 0.895 & not \\
supported
\end{tabular}




\begin{tabular}{|c|c|c|c|c|c|c|c|}
\hline $\begin{array}{l}\text { There is an } \\
\text { influence of } \\
\text { ECE on GPI }\end{array}$ & ECE $->$ GPI & 0.004 & 0.003 & 0.106 & 0.034 & 0.973 & $\begin{array}{l}\text { not } \\
\text { supported }\end{array}$ \\
\hline $\begin{array}{l}\text { There is an } \\
\text { influence of EK } \\
\text { on GPI }\end{array}$ & EK -> GPI & 0.196 & 0.191 & 0.073 & 2.674 & 0.008 & supported \\
\hline $\begin{array}{l}\text { There is a } \\
\text { Positive impact } \\
\text { of Masculinity } \\
\text { on ECE }\end{array}$ & $\begin{array}{l}\text { Masculinity } \\
\text {-> ECE }\end{array}$ & -0.024 & -0.017 & 0.083 & 0.289 & 0.773 & $\begin{array}{l}\text { not } \\
\text { supported }\end{array}$ \\
\hline $\begin{array}{l}\text { There is a } \\
\text { Positive impact } \\
\text { of Masculinity } \\
\text { on EK }\end{array}$ & $\begin{array}{l}\text { Masculinity } \\
\text {-> EK }\end{array}$ & -0.248 & -0.258 & 0.118 & 2.114 & 0.035 & supported \\
\hline $\begin{array}{l}\text { There is } \\
\text { influence } \\
\text { Masculinity on } \\
\text { GPI }\end{array}$ & $\begin{array}{l}\text { Masculinity } \\
\text {-> GPI }\end{array}$ & 0.13 & 0.129 & 0.084 & 1.55 & 0.121 & $\begin{array}{l}\text { not } \\
\text { supported }\end{array}$ \\
\hline $\begin{array}{l}\text { There is a } \\
\text { Positive impact } \\
\text { of Masculinity } \\
\text { on NEP }\end{array}$ & $\begin{array}{l}\text { Masculinity } \\
\text {-> NEP }\end{array}$ & 0.055 & 0.058 & 0.06 & 0.906 & 0.365 & $\begin{array}{l}\text { not } \\
\text { supported }\end{array}$ \\
\hline $\begin{array}{l}\text { There is an } \\
\text { influence of NEP } \\
\text { on GPI }\end{array}$ & NEP -> GPI & 0.065 & 0.06 & 0.139 & 0.473 & 0.636 & $\begin{array}{l}\text { not } \\
\text { supported }\end{array}$ \\
\hline $\begin{array}{l}\text { There is a } \\
\text { Positive impact } \\
\text { of Power } \\
\text { distance on ECE }\end{array}$ & $\begin{array}{ll}\text { Power } & \\
\text { distance } \quad-> \\
\text { ECE }\end{array}$ & -0.058 & -0.066 & 0.073 & 0.799 & 0.425 & $\begin{array}{l}\text { not } \\
\text { supported }\end{array}$ \\
\hline $\begin{array}{l}\text { There is a } \\
\text { Positive impact } \\
\text { of Power } \\
\text { distance on EK }\end{array}$ & $\begin{array}{ll}\text { Power } & \\
\text { distance } \quad-> \\
\text { EK }\end{array}$ & 0.058 & 0.059 & 0.101 & 0.573 & 0.566 & $\begin{array}{l}\text { not } \\
\text { supported }\end{array}$ \\
\hline $\begin{array}{l}\text { There is a } \\
\text { Positive impact } \\
\text { of Power } \\
\text { distance on NEP }\end{array}$ & $\begin{array}{l}\text { Power } \\
\text { distance } \quad-> \\
\text { NEP }\end{array}$ & -0.099 & -0.102 & 0.067 & 1.475 & 0.14 & $\begin{array}{l}\text { not } \\
\text { supported }\end{array}$ \\
\hline $\begin{array}{l}\text { There is a } \\
\text { Positive impact } \\
\text { of Uncertainty } \\
\text { avoidance on } \\
\text { ECE }\end{array}$ & $\begin{array}{l}\text { Uncertainty } \\
\text { Avoidance_ } \\
\text {-> ECE }\end{array}$ & 0.474 & 0.479 & 0.079 & 5.982 & 0 & supported \\
\hline
\end{tabular}




\begin{tabular}{|c|c|c|c|c|c|c|c|}
\hline $\begin{array}{l}\text { There is a } \\
\text { Positive impact } \\
\text { of Uncertainty } \\
\text { avoidance on EK }\end{array}$ & $\begin{array}{l}\text { Uncertainty } \\
\text { Avoidance_ } \\
\text {-> EK }\end{array}$ & 0.203 & 0.193 & 0.145 & 1.405 & 0.16 & $\begin{array}{l}\text { not } \\
\text { supported }\end{array}$ \\
\hline $\begin{array}{l}\text { There is a } \\
\text { Positive impact } \\
\text { of Uncertainty } \\
\text { avoidance GPI }\end{array}$ & $\begin{array}{l}\text { Uncertainty } \\
\text { Avoidance_ } \\
\text {-> GPI }\end{array}$ & -0.134 & -0.136 & 0.117 & 1.141 & 0.254 & $\begin{array}{l}\text { not } \\
\text { supported }\end{array}$ \\
\hline $\begin{array}{l}\text { There is a } \\
\text { Positive impact } \\
\text { of Uncertainty } \\
\text { avoidance on } \\
\text { NEP }\end{array}$ & $\begin{array}{l}\text { Uncertainty } \\
\text { Avoidance_ } \\
\text {-> NEP }\end{array}$ & 0.595 & 0.597 & 0.07 & 8.52 & 0 & supported \\
\hline $\begin{array}{l}\text { There is a } \\
\text { Positive impact } \\
\text { of Long-term } \\
\text { orientation on } \\
\text { ECE }\end{array}$ & $\begin{array}{l}\text { long term } \\
\text { orientation_ } \\
\text {-> ECE }\end{array}$ & 0.108 & 0.113 & 0.102 & 1.063 & 0.288 & $\begin{array}{l}\text { not } \\
\text { supported }\end{array}$ \\
\hline $\begin{array}{l}\text { There is a } \\
\text { Positive impact } \\
\text { of Long-term } \\
\text { orientation on } \\
\text { EK }\end{array}$ & $\begin{array}{l}\text { long term } \\
\text { orientation } \\
\text {-> EK }\end{array}$ & -0.143 & -0.141 & 0.143 & 1 & 0.318 & $\begin{array}{l}\text { not } \\
\text { supported }\end{array}$ \\
\hline $\begin{array}{l}\text { There is an } \\
\text { influence of LTO } \\
\text { on GPI }\end{array}$ & $\begin{array}{l}\text { long term } \\
\text { orientation_- } \\
\text {-> GPI }\end{array}$ & -0.422 & -0.422 & 0.079 & 5.328 & 0 & supported \\
\hline $\begin{array}{l}\text { There is a } \\
\text { Positive impact } \\
\text { of Long-term } \\
\text { orientation on } \\
\text { NEP }\end{array}$ & $\begin{array}{l}\text { long term } \\
\text { orientation } \\
\text {-> NEP }\end{array}$ & 0.06 & 0.065 & 0.073 & 0.826 & 0.409 & $\begin{array}{l}\text { not } \\
\text { supported }\end{array}$ \\
\hline
\end{tabular}

\section{Theoretical Implication}

This study shows that collectivism has significant impact on Environmental Collective efficacy (p-value $0.02<0.05$ ) and New ecological paradigm (p-value $0.038<0.05$ ) but this study also found that collectivism has no significant impact on Environmental knowledge (P-value $0.786>0.05$ ) and green purchase intention ( $\mathrm{p}$-value $0.895>0.05$ ). For Collectivism this reveals that customer's choices for green products are not easily dominated by others. This study supports (Ghazali, et al., 2017) who found that collectivism has no significant impact on green purchase intention. This study contradicts (SHARMA \& ASWAL, 2017) who found a positive relationship between collectivism and green purchase intention. 


\section{Macrothink}

This study has found that Masculinity has no significant impact on Environmental Collective Efficacy ( $\mathrm{P}$ value $0.773>0.05$ ) and New ecological paradigm ( $\mathrm{p}$ value $0.365>0.05$ ) but Masculinity has significant impact on Environmental Knowledge (P value $0.035<0.05$ ).

Masculinity has no significant impact on green purchase intention (P-value $0.121>0.05)$. It reveals that design, accomplishment, and determination do not significantly influence customer preference for green products. (Ghazali, et al., 2017) It also found that masculinity has no significant impact on green purchase intention.

Power distance has no significant impact on Environmental Collective Efficacy (P-value $0.425>0.05)$, Environmental Knowledge (P-value $0.573>0.05)$ and New Ecological Paradigm (P-value $0.14>0.05$ ). According to (Hofstede, 2011) the Character of harmony is considered between societies is considered low power distance like strong and weak, civilized and uncivilized, rich and poor customers. It can be stated based on these findings that low- power distance society desires for a green product. Hence, in order to capture Pakistani markets with green products, product developers are advised to develop such green products that they will not reveal any social gap. The product developers must integrate such elements in the product that high-end and low-end customers perceive the same, for instance courageous, sharp and convenient while consuming the product.

Uncertainty avoidance has also significant impact on Environmental Collective efficacy (P value $0.000<0.05$ ) and New ecological paradigm ( $\mathrm{P}$ value $0.000<0.05$ ) but uncertainty avoidance has no significant impact on Environmental knowledge ( $\mathrm{P}$ value $0.16>0.05)$.

Uncertainty avoidance has also no significant impact on green purchase intention (P-value $0.254>0.05)$.

Long term Orientation has no significant impact on environmental collective efficacy (P value $0.288>0.05)$, Environmental knowledge $(\mathrm{P}$ value $0.318>0.05)$ and new ecological paradigm (P value $0.409>0.05)$.

This study has found long term orientation has a significant impact on green purchase intention (P-value $0.000<0.05$ ). Based on this result it can be interpreted that Pakistani customers prefer green products most, followed by energy effective characteristics. Energy-saving characteristics of product can be helpful in enhancing customer preferences, since they perceive that they will save money on energy consumption in the long run despite the product have higher prices compared with others (Semenova, 2014) High cost incurred during the acquisition of the product is justified by the savings obtained from lower operating cost in the long term. That's why to obtain a larger share in Pakistani Market, designers must prefer product specifications or characteristics that will contribute long term benefits to customers. For instance life of a product can be increased by (1) giving product-related services like repair and replacement to retain performance of the product, (2) crafting and advancing the product that are easy to be maintained, by which customers can perform self-maintenance services like cleaning and repairing, or crafting and developing the product that could be easy to advance, by which customers can enhance the performance of the product by modifying it. This study contradicts (Sreen, Purbeya, \& Sadarangania, 2018) 
which found that Long-term orientation is insignificantly related to green purchase intention.

This study has also found that Environmental knowledge has significant influence on green purchase intention (P-value $0.008<0.05$ ) but Environmental collective efficacy (P-value $0.973>0.05$ ) and New ecological paradigm ( $\mathrm{P}$-value $0.473>0.05$ ) has no significant influence on green purchase intention. As far as Environmental knowledge is concerned with this study contradicts (Zia-ur-Rehman \& Dost, 2013) which found that Environmental concern does not impact green purchase intention.

Customer preferences should be considered while forming a product design and during product development. Ulrich and Eppinger (2008) reiterated that customer preference is significant and must be analyzed at the initial stage of product development. Customer preferences must be clearly determined for green products. Since numerous characteristics of green products introduced in the market can be explained and accepted differently by customers due to their different cultural values. According to Hofstede (1993), human nature possesses Collectivism, cultural values may distinguish from one society to another. These differences may lead to distinguished choices of customers toward green products. Customers' purchasing intentions will certainly decrease when customers' preferences are mistakenly analyzed. Since the characteristics of green products do not accommodate the customers' cultural values. This can give undesirable results since it is very incredible that environmental sustainability can be achieved by selling green products.

\section{Conclusion}

In summary findings of this study propose that Environmental collective efficacy and new ecological paradigm are not significant predictors of green purchase intention. However, Environmental knowledge is an important predictor of green purchase intention. It is astonishing to observe that direct effect and the mediating effect of environmental collective efficacy, environmental knowledge, and new ecological paradigm are not obvious in this study. Collectivism has no significant impact on green purchase intention (P-value $0.895>$ 0.05) which means that if consumers have a durable culture disposition to support collective values, they might not have high green purchase intention. Specifically, this study also found that Collectivism has a positive mediating effect on the relationship between environmental collective efficacy and green purchase intention. In Pakistan, if consumers likely to admit high adequacy of pro-environmental behavior and to have a durable culture disposition to support collective value altogether, consumers likely to display greater green purchase intention.

As previous studies did not find complete cultural dimensions impact of green purchase intention and mediating variable role of NEP, ECE, and EK. This study has found the relationship and tried to cover the gap, but findings suggest that it with more sample size and different areas are made the part of the research results could be quite satisfactory.

The objective of this study is to evaluate the cultural influence on green purchase intention. Five cultural value dimensions are used in this study out of which Collectivism, Masculinity, Uncertainty avoidance and long-term orientation influence on green purchase intention are 
analyzed. Based on the findings, it can be stated that cultural values play an important role in determining customer preference for green products. Considering the cultural value dimensions in developing the product is important to enhance customer preferences for green products.

This knowledge can be fruitful input to reinforce the business and enhance public policies in Pakistan, in order to achieve sustainable development. Since all customers have not experienced purchasing green products so decreasing customers' doubts is very significant. Eco-labeling can be a useful tool to decrease customer's doubts and help them in making the right decisions when making purchases. However, the Government of Pakistan ensures that products with green tags have fully completed the procedure in contributing to environmental protection. Eco-labeling should be used not only for the specified sector but also for the manufacturing sector, service sector, and the agricultural sector as well. This will promote consumer awareness regarding green products available in the market.

In order to fix customers' long-term orientation choices, a specific strategy should be devised on energy effectiveness for both industrialists and customers. Advancing product features and persistence by giving priority to product services, for instance, developing products that can easily be retained and improved by the customers is also a fruitful approach to match sensible behavior of long-term oriented societies. Last, giving extensive promotion to green products and making products with affordable prices that do not reveal the social gap can be a promising strategy to control the effects of low-power distance dimension on green product choices.

The findings of this study reveal some insights on how cultural values play an important role in determining customer preferences for green products. The key stakeholders such as industrialists must spend on these cultural values considering the current market situation. Since the customers' preferences from one society to another society may differ. A similar research methodology can be used to analyze other regions.

\section{Limitation and Suggestion}

There are several limitations to this study. First of all, this study was analyzed with small sample data that's why future studies should increase sample size and collect the date from different cities of Pakistan so that results can be more satisfactory. Future studies should include demographics such as age, gender, location, and income as antecedents of green purchase intention. Other variables may exist that influence green purchase intention other than the New Ecological Paradigm, Environmental Collective Efficacy, and Environmental knowledge. Future studies may analyze the moderating effect of collectivism as well or any other cultural value dimensions.

\section{References}

Andreas Hombur, A. S. (2006). Explaining pro-environmental behavior with the cognitive theory of stress. Journal of Environmental Psychology, 1-14. https://doi.org/10.1016/j.jenvp.2006.03.003 
Azjen, I. (1980). Understanding attitudes and predicting social behavior. Englewood Cliffs.

Bamberg, S., \& Möser, G. (2007). Twenty years after Hines, Hungerford, and Tomera: A new meta-analysis of psycho-social determinants of pro-environmental behaviour. Journal of Environmental Psychology, 27(1), 14-25. https://doi.org/10.1016/j.jenvp.2006.12.002

Bandura, A. (2000). Exercise of Human Agency Through Collective Efficacy. Current Directions in Psychological Science, 75-78. https://doi.org/10.1111/1467-8721.00064

Blijlevens, J., Creusen, M. E., \& Schoormans, J. P. (2009). How consumers perceive product appearance: The identification of three product appearance attributes. International Journal of Design, 3(3).

Bloch, P. H. (1995). Seeking the ideal form: Product design and consumer response. Journal of Marketing, 59(3), 16-29. https://doi.org/10.1177/002224299505900302

Bonniface, \& Henley. (2016). A drop in the bucket': Collective efficacy perceptions and environmental behavior. Australian Journal of Social Issues, 345-358. https://doi.org/10.1002/j.1839-4655.2008.tb00107.x

Brucks, M. (1985). The Effects of Product Class Knowledge on Information Search Behavior. Journal of Consumer Research, 1-16. https://doi.org/10.1086/209031

Cho, Y. N., Thyroff, A., Rapert, M., Park, S. Y., \& Lee, H. (2013). To be or not to be green: Exploring individualism and collectivism as antecedents of environmental behavior. Journal of Business Research, 1052-1059. https://doi.org/10.1016/j.jbusres.2012.08.020

Crilly, N., Moultrie, J., \& Clarkson, P. J. (2004). Seeing things: consumer response to the visual domain in product design. Design studies, 25(6), 547-577. https://doi.org/10.1016/j.destud.2004.03.001

Deborah J.C. Brosdahl, J. M. (2010). Consumer Knowledge of the Environmental Impacts of Textile and Apparel Production, Concern for the Environment, and Environmentally Friendly Consumption Behavior. Journal of Textile and Apparel Technology and Management.

Donthu, N., \& Yoo, B. (1998). Cultural Influences on Service Quality Expectations. Journal of Service Research, 178-186. https://doi.org/10.1177/109467059800100207

Dunlap, R. E., \& Liere, K. D. (2008). The "New Environmental Paradigm". The Journal of Environmental Education, 19-28. https://doi.org/10.3200/JOEE.40.1.19-28

Dunlap, R. E., \& Van Liere, K. D. (1978). A proposed measuring instrument and preliminary results: The 'New Environmental Paradigm'. Journal of Environmental Education, 9(1), 10-19. https://doi.org/10.1080/00958964.1978.10801875

Dunlap, R. E., Van Liere, K. D., Mertig, A. G., \& Jones, R. E. (2000). New trends in measuring environmental attitudes: measuring endorsement of the new ecological paradigm: a revised NEP scale. Journal of Social Issues, 56(3), 425-442. https://doi.org/10.1111/0022-4537.00176 


\section{Macrothink}

International Journal of Industrial Marketing

ISSN 2162-3066

2020, Vol. 5, No. 1

Ellen, P. S. (1994). Do we know what we need to know? Objective and subjective knowledge effects on pro-ecological behaviors. Journal of Business Research, 43-52. https://doi.org/10.1016/0148-2963(94)90067-1

Fornell, C., \& Larcker, D. F. (1981). Evaluating Structural Equation Models with Unobservable Variables and Measurement Error. Journal of Marketing Research, 39-50. https://doi.org/10.1177/002224378101800104

Frías, D. M., Rodríguez, M. A., Alberto Castañeda, J., Sabiote, C. M., \& Buhalis, D. (2012). The formation of a tourist destination's image via information sources: The moderating effect of culture. International Journal of Tourism Research, 14(5), 437-450. https://doi.org/10.1002/jtr.870

Furrer, O., Liu, B. S. C., \& Sudharshan, D. (2000). The relationships between culture and service quality perceptions: Basis for cross-cultural market segmentation and resource allocation. Journal of Service Research, 2(4), 355-371. https://doi.org/10.1177/109467050024004

Gerald, E., \& Fryxell, C. W. (2003). The Influence of Environmental Knowledge and Values on Managerial Behaviours on Behalf of the Environment: An Empirical Examination of Managers in China. Journal of Business Ethics, 45-69. https://doi.org/10.1023/A:1024773012398

Ghazali, I., Abdul-Rashid, S. H., Dawal, S. Z., Aoyama, H., Tontowi, A. E., \& Sakundarini, N. (2017). Cultural Influences on Choosing Green Products: An Empirical Study in MALAYSIA. Sustainable Development. https://doi.org/10.1002/sd.1685

Gul, M. C. (2013). Long-term Orientation, Perceived Consumer Effectiveness, and Environmentally Conscious Consumer Behavior: The Case of Turkey. Internation Journal for Marketing Studies. https://doi.org/10.5539/ijms.v5n5p24

Hair, J. F., Matthews, L. M., Matthews, R. M., \& Sarstedt, M. (2017). PLS-SEM or CB-SEM: updated guidelines on which method to use. Int. J. Multivariate Data Analysis, 107-123. Retrieved from https://www.google.com/url?sa=t\&rct=j\&q=\&esrc=s\&source=web\&cd=1\&cad=rja\&uact=8 \&ved=2ahUKEwj8mJ316LTiAhWBxIsKHbO2ApsQFjAAegQIBxAC\&url=https\%3A\%2F\% 2Fwww.researchgate.net\%2Fprofile\%2FThien_Sang_Lim\%2Fpost\%2FWhat_papers_or_ma nuals_do_you_recommend_the_most_to

Hawcroft, L. J., \& Milfont, T. L. (2010). The use (and abuse) of the new environmental paradigm scale over the last 30 years: A meta-analysis. Journal of Environmental Psychology, 30(2), 143-158. https://doi.org/10.1016/j.jenvp.2009.10.003

Hines, J. M., Hungerford, H. R., \& Tomera, A. N. (1987). Analysis and synthesis of research on responsible environmental behavior: A meta-analysis. The Journal of Environmental Education, 18(2), 1-8. https://doi.org/10.1080/00958964.1987.9943482

Hofstede, G. (1980). Motivation, leadership, and organization: do American theories apply 
abroad?

Organizational

Dynamics,

$9(1)$

$42-63$.

https://doi.org/10.1016/0090-2616(80)90013-3

Hofstede, G. (1993). Cultural constraints in management theories. Academy of Management Perspectives, 7(1), 81-94. https://doi.org/10.5465/ame.1993.9409142061

Hofstede, G. (2011). Dimensionalizing cultures: The Hofstede model in context. Online Readings in Psychology and Culture, 2(1), 8. https://doi.org/10.9707/2307-0919.1014

Horne, R. E. (2009). Limits to labels: The role of eco-labels in the assessment of product sustainability and routes to sustainable consumption. International Journal of Consumer Studies, 175-182. https://doi.org/10.1111/j.1470-6431.2009.00752.x

Howarth, G., \& Hadfield, M. (2006). A sustainable product design model. Materials \& Design, 27(10), 1128-1133. https://doi.org/10.1016/j.matdes.2005.03.016

Jain, S. K., \& Kaur, G. (2004). Green Marketing: An Attitudinal and Behavioural Analysis of Indian Consumers. Global Business Review, 187-205. https://doi.org/10.1177/097215090400500203

Kim, Y., \& Choi, S. M. (2005). Antecedents of Green Purchase Behavior: an Examination of Collectivism, Environmental Concern, and Pce. Association for Consumer Research, 592-599.

Laroche, M., Bergeron, J., \& Barbaro-Forleo, G. (2001). Targeting consumers who are willing to pay more for environmentally friendly products. Journal of Consumer Marketing, 18(6), 503-520. https://doi.org/10.1108/EUM0000000006155

Lee, C., Song, B., \& Park, Y. (2012). Design of convergent product concepts based on functionality: An association rule mining and decision tree approach. Expert Systems with Applications, 39(10), 9534-9542. https://doi.org/10.1016/j.eswa.2012.02.099

Lee, Y. K. (2017). A Comparative Study of Green Purchase Intention Korean and Chinese Consumers: The Moderating Role of Collectivism. sustainibility, 780-714. https://doi.org/10.3390/su9101930

Liobikienè, G., Mandravickaitè, J., \& Bernatonienè, J. (2016). Theory of planned behavior approach to understanding the green purchasing behavior in the EU: A cross-culture study. Ecological Economics, 38-46. https://doi.org/10.1016/j.ecolecon.2016.02.008

Luchs, M. G., Naylor, R. W., Irwin, J. R., \& Raghunathan, R. (2010). The sustainability liability: Potential negative effects of ethicality on product preference. Journal of marketing, 74(5), 18-31. https://doi.org/10.1509/jmkg.74.5.018

McCarty, J. A., \& Shrum, L. (2001). The Influence of Individualism, Collectivism, and Locus of Control on Environmental Beliefs and Behavior. Journal Of Public Policy \& Marketing, 93-104. https://doi.org/10.1509/jppm.20.1.93.17291

Michael Jay Polonsky, A. V. (2012). The impact of general and carbon-related environmental knowledge on attitudes and behaviour of US consumers. Journal of Marketing Management, 
238-263. https://doi.org/10.1080/0267257X.2012.659279

Michel Laroche, J. B. F. (2001). Targeting Consumers Who Are Willing to Pay More for Environmentally Friendly Products. Journal of Consumer Marketing, 503-520. https://doi.org/10.1108/EUM0000000006155

Mobley, C., Vagias, W. M., \& DeWard, S. L. (2010). Exploring additional determinants of environmentally responsible behavior: The influence of environmental literature and environmental attitudes. Environment and Behavior, 42(4), 420-447. https://doi.org/10.1177/0013916508325002

Moon, J., Chadee, D., \& Tikoo, S. (2008). Culture, product type, and price influences on consumer purchase intention to buy personalized product onlinen. Journal of Business Research, 31-39. https://doi.org/10.1016/j.jbusres.2006.05.012

Nelson A. Barber, C. T. (2009). Wine consumers' environmental knowledge and attitudes: Influence on willingness to purchase. International Journal of Wine Research, 59-72. https://doi.org/10.2147/IJWR.S4649

Nguyen, T. N., Lobo, A., \& Greenland, S. (2017). The Influence of Cultural Values on Green Purchase Behaviour. Marketing Intelligence and planning, 377-396. https://doi.org/10.1108/MIP-08-2016-0131

Salmi, A. (2008). Culture and design in emerging markets: the case of mobile phones in Russia. Journal of Business \&amp; Industrial Marketing, 23(6), 384-394. https://doi.org/10.1108/08858620810894436

Scott, D., \& Willits, F. K. (1994). Environmental attitudes and behavior: A Pennsylvania $\begin{array}{llll}\text { survey. Environment and } & \text { 239-260. }\end{array}$ https://doi.org/10.1177/001391659402600206

Seijts, G. H. (2000). The effects of goal setting and group size on performance in a social dilemma. Canadian Journal of Behavioural Science / Revu Canadiennene des sciences du comportement, 32(2), 104-116. https://doi.org/10.1037/h0087105

Semenova, P. C. (2014). Energy Performance and Housing Prices. Sustainable Development, 404-419. https://doi.org/10.1002/sd.1566

Şener, A., \& Hazer, O. (2008). Values and sustainable consumption behavior of women: a Turkish sample. Sustainable Development, 16(5), 291-300. https://doi.org/10.1002/sd.329

Sharma, K., \& Aswal, C. (2017). Green Purchase Intentions, Collectivi, m and Materialism: An Empirical Investigation. The Delhi University Journal of the Humanities and the Social Sciences, 33-50.

Shrout, P. E., \& Bolger, N. (1986). Mediation in Experimental and Nonexperimental Studies: New Procedures and Recommendations. Psychological Methods, 422-45. https://doi.org/10.1037/1082-989X.7.4.422

Sreen, N., Purbeya, S., \& Sadarangania, P. (2018). Impact of culture, behaviour, and gender 


\section{Macrothink}

on green purchase intention. Journal of Retailing and Consumer Services, 177-189. https://doi.org/10.1016/j.jretconser.2017.12.002

Srite, M. (1999). The influence of national culture on the acceptance and use of information technologies: An empirical study. AMCIS 1999 Proceedings, 355.

Suri, R., \& Monroe, K. B. (2003). The effects of time constraints on consumers' judgments of prices and products. Journal of Consumer Research, 30(1), 92-104. https://doi.org/10.1086/374696

Tanner, C., \& Wölfing Kast, S. (2003). Promoting sustainable consumption: Determinants of green purchases by Swiss consumers. Psychology \& Marketing, 20(10), 883-902. https://doi.org/10.1002/mar.10101

Thøgersen, J., \& Ölander, F. (2006). The Dynamic Interaction of Personal Norms and Environment-Friendly Buying Behavior: A Panel Study. Journal of Applied Social Psychology, 1758-1780. https://doi.org/10.1111/j.0021-9029.2006.00080.x

Windrum, P., Ciarli, T., \& Birchenhall, C. (2009). Environmental impact, quality, and price: Consumer trade-offs and the development of environmentally friendly technologies. Technological Forecasting and Social Change, 552-566. https://doi.org/10.1016/j.techfore.2008.04.012

Yoo, B., \& Donthu, N. (2005). The effect of personal cultural orientation on consumer ethnocentrism: Evaluations and behaviors of US consumers toward Japanese products. Journal of International Consumer Marketing, 18(1-2), 7-44. https://doi.org/10.1300/J046v18n01_02

Zia-ur-Rehman, \& Dost, M. K. (2013). Conceptualizing Green Purchase Intention in Emerging Markets: An Empirical Analysis on Pakistan. International Academic Conference Proceedings. Istumbul, turkey.

\section{Copyright Disclaimer}

Copyright for this article is retained by the author(s), with first publication rights granted to the journal.

This is an open-access article distributed under the terms and conditions of the Creative Commons Attribution license (http://creativecommons.org/licenses/by/3.0/). 